\title{
Corporate Social Responsibility in a Comparative Perspective
}

Cynthia Williams

Osgoode Hall Law School of York University, cwilliams@osgoode.yorku.ca

Ruth V. Aguilera

Source Publication:

Oxford Handbook of Corporate Social Responsibility. Oxford, UK: Oxford University Press, 2008.

Follow this and additional works at: https://digitalcommons.osgoode.yorku.ca/scholarly_works

\section{Recommended Citation}

Williams, Cynthia, and Ruth V. Aguilera. "Corporate Social Responsibility in a Comparative Perspective." Oxford Handbook of Corporate Social Responsibility. Eds. Oxford Handbook of Corporate Social Responsibility edited by Andrew Crane, Dirk Matten, Abagail McWilliams, Jeremy Moon, and Donald S. Siegel. Oxford, UK: Oxford University Press, 2008. p. 452-472.

This Book Chapter is brought to you for free and open access by the Faculty Scholarship at Osgoode Digital Commons. It has been accepted for inclusion in Articles \& Book Chapters by an authorized administrator of Osgoode Digital Commons. 


\title{
CORPORATE SOCIAL RESPONSIBILITY IN A COMPARATIVE PERSPECTIVE
}

\author{
CYNTHIA A. WILLIAMS \\ RUTH V. AGUILERA
}

\section{INTRODUCTION}

COMPARATIVE studies of corporate social responsibility (CSR) are relatively rare, certainly as contrasted with other related fields, such as comparative corporate governance or comparative corporate law. This is to be expected in a field, CSR, that is still 'emergent' (McWilliams et al., 2006). While theoretical perspectives on corporate social performance or stakeholder management have been developed for over two decades (Carroll, 1979; Freeman, 1984; Donaldson and Preston, 1995; Clarkson, 1995; McWilliams and Siegel, 2001), it is only in the last decade that businesses have begun to exhibit serious evidence of CSR in their strategic management and stakeholder socialx reporting.

Moreover, the field of empirical CSR research generally has been hampered by the lack of a consistent definition of the construct of CSR, as well as its operationalization and measurement, as recently pointed out by McWilliams et al. (2006) and Rodríguez et al. (2006). This lack of consistency of CSR definitions 
across studies makes it difficult to evaluate and compare the findings from different studies because they usually refer to different dimensions of CSR. Most research on CSR has focused on the consequences of CSR implementation-or lack of implementation - on financial performance with little attention to comparative issues (e.g. McWilliams and Siegel, 2000; Margolis and Walsh, 2003; Barnett and Salomon, 2006), the main exception being a meta-analysis which includes studies conducted in the context of different countries (Orlitzky et al., 2003). We know, however, from existing research that individuals are likely to have distinct expectations and attitudes towards CSR contingent on the industry (Bansal and Roth, 2000; Strike et al., 2006) or societal culture (Waldman et al., 2006) in which they are embedded.

Notwithstanding these difficulties, comparative studies of CSR illuminate theories of corporate governance and relationships amongst the various actors that both comprise and influence companies. Thus it is of value to attend to the studies that have been conducted, and to develop research protocols to encourage further comparative work.

Studies that are comparative in this field differ in how they define the comparative unit of analysis, and such differences often have methodological implications. Where countries or other geographical units such as continents are used as the basis for comparing CSR environments, studies then tend to use either comparative legal analysis or comparative institutional analysis. Fewer studies than might be expected use individual countries as the unit of analysis, but this is likely inherent in the nature of the CSR challenge itself. CSR as a rapidly developing business strategy (and not simply a theory in the management literature), is a response to globalization and the extension of global multinational enterprises ('MNEs') across countries, with the implication that state control over such enterprises is rapidly fragmenting (Logsdon and Wood, 2002; Zumbansen, 2006). Thus, broader units of analysis that reflect these global challenges are often used.

One approach that has used both comparative legal analysis and comparative institutional analysis has been to compare the perspectives and strategies on CSR inherent in different corporate governance systems, such as contrasting AngloAmerican versus Continental European approaches to CSR. A number of these studies will be discussed in the next section. Other studies have used a 'most similar case' approach to show differences in companies' approaches to CSR in countries with seemingly similar socio-political traditions within these corporate governance systems. Comparisons between the United States and the UK are of particular note because they have implications for theories about corporate governance systems in addition to CSR, as discussed in below.

Other comparative approaches examine pressures on companies across a broad range of countries at one level of analysis or on one dimension. A developing body of scholarship compares, across countries, the actions or perspectives of employees, consumers, institutional investors or non-governmental organizations (NGOs) to 
engage in CSR initiatives. Some of these studies will be summarized below, with a particular emphasis on differences in perspectives of top management teams (TMT) and consumers between geographic regions. Other approaches look at companies' CSR actions more directly, such as studies of differences in corporate social reporting across countries or differences in companies' community partnerships or partnerships with NGOs across countries. A number of these studies will be discussed below. Recent research in international business discusses the strategic management of CSR issues by global companies operating in different countries, summarized in the penultimate section. A conclusion follows.

\section{COMPARISONS OF LEGAL AND INSTITUTIONAL FACTORS SHAPING CSR}

\section{Comparative Legal Analysis regarding CSR}

Today, scholarship at the intersection of law and sociology 'decenters' the state as a locus of regulatory power in favor of a more nuanced view of various systems of control that have an impact on conduct, including law, norms, industry and professional practices, markets and even architecture (Lessig, 1999; Scott, 2003). And yet comparative legal analysis still has much to offer in understanding CSR, since the laws governments pass to encourage CSR are uniquely powerful, in at least three respects. First, the standards established by laws and mandatory regulation, while not immediately translated into action in any realistic portrait of global organizational practice, have a particularly strong influence on establishing social expectations about responsible corporate behavior. The social expectations then act as a 'focal point' around which firms structure their behavior (McAdams and Nadler, 2005). Second, once the social expectation is created, a number of other forces, including consumer demands, institutional investor demands, community demands, and NGO demands, interact to create incentives for firms to meet the standards set out in the law (Kagan et al., 2003), whether enforcement is a realistic threat or not. Third, the laws and policies that governments enact send a strong signal about the importance of a subject-a signal that, as regards CSR, is amplified by the business culture in the country, consumers' interests, institutional investors' actions, the corporate governance regime, NGOs' effectiveness, and the individualistic versus collectivist nature of the country's underlying political and social philosophy.

An example of these factors, given government leadership in the administration of Prime Minister Tony Blair, is the emphasis by the UK government in promoting CSR (Moon, 2004; Aaronson and Reeves, 2002). In 1996, the Blair administration 
promulgated regulations, since followed by Belgium, France, Germany, and the Netherlands, that require the trustees of occupational pension funds to adopt Statements of Investment Principles detailing the way social and environmental information is taken into account in constructing investment portfolios. This law has had an important effect on the behavior of the largest pension funds, causing them to ask questions of asset managers about their CSR records, and in turn fueling greater interest in, and investment in, socially responsible investment (SRI) (Williams and Conley, 2005). As one example of its policy encouragement, the UK government was persuaded that extractive industry revenue transparency would help to promote government accountability, political stability, and reduce poverty in many 'resource rich yet poor' countries. It also realized that such political stability would be advantageous to two of its flagship companies, BP and Shell, but only so long as BP and Shell did not suffer competitive disadvantages from losing oil concessions to companies that did not require revenue transparency. As a result, Prime Minister Tony Blair became a leader in the recent Extractive Industry Transparency Initiative to encourage companies in the oil, gas, and mining industry to 'Publish What They Pay', that is to publish the payments companies have made to countries to obtain concessions to extract oil, gas, or minerals (Williams, 2004).

Given the UK's leadership role in encouraging CSR, it is not surprising that comparative studies show that companies in the UK have higher rates of stakeholder engagement and social reporting than companies in every other European country except Norway, even as European companies generally lead the world on these metrics (Welford, 2005). Future work that investigates the effect of government laws and policies in the UK in producing these high rates of reporting, and that differentiates between legal factors and institutional factors such as institutional investor pressures, top management team (TMT) leadership, labor or NGO activism, in producing these high rates of stakeholder engagement and social reporting, would be valuable.

With respect to developing countries, one predominant CSR concern is that governments will ignore corporate irresponsibility or refuse to enforce protective labor or environmental standards in the law as an inducement to foreign investment (Aman, 2001). China, for instance, has strong rights to collective bargaining, by law, and yet thousands of people in jail for trying to exercise those rights (Diamond, 2003). Yet, some developing country governments are promulgating laws requiring higher standards of responsible environmental or social conduct in order to compete for foreign capital and institutional investment, in addition to competing on the more familiar 'rule of law' issues of contract and property law rights, financial transparency, intellectual property protection, and reduced government corruption (Hebb and Wojcik, 2004). Comparing these legal developments in different emerging economies would be valuable as a basis for further understanding of the relationship of law and development and of the contribution of CSR, if any, to economic development. 
Chapple and Moon (2005) have found that CSR in Asia is unrelated to preexisting levels of economic development, but is related to the extent to which domestic companies engage in international trade, even where that trade is with other Asian nations. Conversely it would be useful to study whether 'imports' of CSR standards into developing countries lead to greater economic development or enhance rule of law norms. This strand of comparative legal analysis of CSR would take up the suggestion of Ahlering and Deakin (2005) to examine more carefully the complementarities between legal and economic institutions in promoting economic development.

\section{Comparative Institutional Analysis}

Comparative institutional analysis proceeds from the assumption that formal institutions, such as constitutions, laws, and government policies, interact with both informal institutions such as social norms and 'mental modes of analysis' (Doh and Guay, 2006), and organizations such as business entities, labor organizations, and civil society, to produce unique cultural and institutional frameworks for company action (Aguilera and Jackson, 2003; Campbell, 2005; Ahlerling and Deakin, 2005). One such recent study is that of Doh and Guay, which explored differences in the institutional environments in the European Union (EU) versus the United States with respect to government policy-making, corporate strategies to affect government policy-making, and NGO activism (Doh and Guay, 2006). Doh and Guay looked at differences in NGO strategies and power in the EU versus United States with respect to three CSR policy issues, those of genetically modified foods, climate change, and HIV/AIDS drug pricing. They conclude that the more influential position of NGOs in the EU is explained by differences in the processes of policy-making in the EU, in that there are explicit avenues for including the views of business, labor, and civil society as important policies are being developed at the EU level, and by differences in the political legacies of the two regions, given the social-democratic traditions in the EU versus the more individualistic and libertarian strands of political thought in the United States (Doh and Guay, 2006).

Another comparative institutional study that evaluates the legal requirements and market incentives to engage in CSR throughout the EU, with a particular emphasis on Spain, is Cuesta González and Valor Martinez (2004). Their article includes a comprehensive description of regulations and government policies across the EU to encourage CSR initiatives and to require greater disclosure of social and environmental information that should be useful to future researchers. The authors view the most important aspects of CSR, labor relationships, and environmental protection, as incorporated into the regulatory framework in Europe, but that social and environmental information and company responsibility for subsidiaries' actions or their supply chains are 'gaps' in the framework that leave room for 
voluntary CSR. Cuesta González and Valov Martínez (2004) note that most of the laws in Europe to address these gaps seek to create market incentives to encourage CSR, such as recognition of best practices, awareness campaigns, and the like, designed to encourage consumers to use their purchasing power to promote CSR, which the authors conclude is indicative of governments 'not strongly committed to these [CSR] initiatives' (p. 284) The authors evaluate the disclosure requirements as an effort to overcome information asymmetries about companies' CSR activities, such that capital and consumer markets can respond with greater precision to companies' records. Generally, though, the authors conclude that consumer and investor market incentives are too weak in Spain, the specific country they examine in detail, and so specific regulations would be required to increase the value of required disclosure, to expand fiduciary duties of company directors and managers, and to hold the public sector accountable for its social, economic and environmental performance.

A trenchant suggestion to extend institutional comparative work of this type comes from Zumbansen (2006: 18), who posits that the questions of defining companies' social responsibilities and examining convergence and divergence in corporate governance cannot fully be answered until companies themselves are examined as 'institutions of social learning' within unique socio-economic and regulatory contexts, each shaped by national path dependencies and international comparisons. While some comparative social responsibility work is starting in that direction, by combining attention to comparative institutional and regulatory context with examining companies' actions in those different contexts, Zumbansen is undoubtedly correct to call for more systematic attention to how companies respond and 'learn' within different regulatory and institutional environments.

\section{Implications of Comparative CSR for Understanding Corporate Governance Systems}

Studies of comparative CSR have implications for our understanding of theories of corporate governance. Corporate governance scholars have roughly divided the world into the Anglo-American 'outsider' system versus the Continental European and Japanese 'insider' systems, which divisions have been suggested to map onto shareholder versus stakeholder views of the firm and onto different cognitive styles in various cultures (Licht, 2004). Yet, recent studies of comparative CSR suggest that these conceptual demarcations need substantial qualification. In particular, a number of studies show that legal developments and institutional contexts in Britain concerning CSR show important similarities with Europe, and related contrasts with the United States, thus casting doubt on a unified 'Anglo-American' system of corporate governance. 
Matten and Moon (2004) have compared CSR in Europe to that in the United States, and have proposed a conceptual framework of 'explicit' versus 'implicit' CSR, while recognizing that these are matters of emphasis, not wholly dichotomous states. They define explicit CSR as that seen in the United States, where companies volunteer to address important social and economic issues through their CSR policies, in significant part because of less stringent legal requirements than in Europe for such things as health-care provision, employee's rights, environmental protection, and so on (p. 9). In contrast, in Europe and the UK, responsibility for these issues is undertaken as part of a company's legal responsibilities, and thus CSR is 'implicit' in the way the company does business (ibid). The results of their work suggests that Britain shares with Europe institutional and legal features that reflect its European character, so that business is assigned, by law, 'an agreed share of responsibility for society's interests and concerns' (Matten and Moon, 2004: 9). In this analysis, Matten and Moon (2004) have implicitly interrogated the question of whether there is an 'Anglo-American' system of corporate governance, at least at the level of agreed conclusions on the perennial debates of the corporate purpose, and whether shareholders only, or stakeholders in addition, should comprise the full ambit of managerial strategy and concern.

Similarly, Armour et al. (2003) and Deakin (2005) have looked critically at the claim that the UK's system of corporate governance shares with the United States primacy for the interests of shareholders. They find considerable support for the idea that the institutional context in Britain-particularly protections of employees in insolvency law and in labor law-casts doubt on a unitary 'Anglo-American' view of corporate governance. They also describe some influential pension fund shareholders in London as concerned with broader stakeholder interests, observing that ' $[\mathrm{s}]$ ome institutional investors are beginning to use their influence to monitor performance by companies across a range of social and environmental issues that impact upon stakeholders' (Armour et al., 2003).

Williams and Conley (2005) and Aguilera et al. (2006) have followed Armour et al. (2003) in evaluating legal and institutional factors in the UK and the City of London that are encouraging a divergence between the United States and the UK in the emphasis given in the two countries' capital markets to companies' social and environmental role. Legal factors include more required disclosure of social and environmental information by publicly listed companies in the UK than in the United States; and the required disclosure by pension fund trustees of the extent to which social and environmental issues are considered in constructing their investment portfolios (Williams and Conley, 2005). Institutional factors include: (a) differences in the composition of institutional investors in the two markets, with a higher percentage of institutional investors in the UK being pension funds and insurance companies with longer time-horizons for investment than the mutual funds that have dominated in the United States; $(b)$ 'soft law' encouragement in the UK by the highly influential Cadbury Commission of institutional investor engagement 
with portfolio companies; and $(c)$ encouragement of attention to CSR issues by the Institutional Shareholders Committee, which represents over $80 \%$ of institutional investment in the UK (Aguilera et al., 2006; Williams and Conley, 2005). Further research should re-evaluate these institutional factors as private equity investors and hedge funds become a more substantial percentage of each market, in order to determine if the time-frames for investment are being affected by shifts in the composition of the two markets, since concern with longer-term risks is part of investors' concerns with CSR. It would be particularly important to evaluate if the priority given to CSR issues by City of London investors, as previously described, is being eroded.

\section{ACtOR-CENTERED Cross-National COMPARISONS: ATtTITUES OF MANAGERS AND Consumers TOWARDS CSR}

As remarked above, comparative research can be approached from multiple perspectives. For example, it can compare a given issue, such as CSR transparency, across different countries or different industries. Another route is to take an actorcentered perspective where one analyzes the differences and similarities in the strategy and capacity of different stakeholders to influence CSR issues at the firm, government, or societal level. A third comparative route might be to combine the two comparative methods, looking at different CSR issues as well as stakeholder reactions across regions, as did Doh and Guay (2006) in the research discussed above. Thus, in conducting comparative and qualitative research using a case study methodology to assess the roles of NGOs in the United States and Europe in exercising influence on three CSR issues (trade and regulation of genetically modified organisms, relaxation of intellectual property protection for HIV/AIDS medications, and the Kyoto Agreement on climate change), they were able to show that differences in these two regions in the structure of political institutions and the strategies of interests groups directly determined how CSR is perceived and put into practice by the different firms, activists, and governments. This type of comparative research is difficult to conduct, given the complexity of data collection, and the research design is challenging if we are to rely on survey methodology.

One CSR research question which has received some comparative attention and hence is worthwhile synthesizing and discussing is how stakeholders across different institutional and cultural settings approach and react to CSR issues. In particular, there is some interesting work looking at the role of managers and consumers across countries. We discuss each of them in turn. 


\section{Comparative TMT Attitudes towards CSR}

There is an extensive literature which conceptually justifies why managerial values and attitudes towards CSR in a given organization, industry, or national context are likely to have a strong influence on firm-level CSR outcomes (e.g. Hay and Gray, 1974; Hemingway and Maclagan, 2004; Hemingway, 2005; Aguilera et al., forthcoming). In addition, the research finding that individual and organizational values, regardless of country-level factors, are significant predictors of CSR managerial behavior has also been confirmed by multiple empirical studies in different national and industry contexts. For example, Vitell and Paolillo's (2004) cross-cultural study of the antecedents of the perceived role of social responsibility in the decisionmaking process of managers from Spain, Turkey, Great Britain, and the United States shows that managerial CSR decisions and likelihood of success are shaped by the managers' individual ethical perspective and their organizational culture. Similarly, Waldman et al.'s (2006) cross-national and longitudinal study of culture and leadership precursors shows that both CEO visionary leadership and individual integrity are key factors associated with corporate social responsibility values. Finally, in the context of one emerging country, Branzei et al.'s (2004) study of 360 Chinese firms uncovers that leaders' cognitions influence the formation of novel responses to much-needed corporate greening strategies. One of the implications of these three empirical studies is that individual and organizational contexts do matter.

In light of these findings at the individual level, we would like to turn our attention to how managers might display different attitudes and values towards CSR given the cultural and historical differences across countries, regions, and even industrial fields. In other words, we seek to introduce a more systematic comparative perspective as well as to explore the distinct expectations that society (and societal actors) are likely to impose on TMTs as a team and as individual managers on their engagement in CSR issues. In effect, we expect a wide range of variation despite increasing global convergence in business practices. That expectation is based on the extensive evidence developed by international management scholars showing that managers, and more generally top management teams (TMTs), behave differently across countries because they are highly influenced by the national cultural norms of work (e.g. Hofstede, 1980, 2001; Schwartz, 1994; Triandis, 1995), organizational culture (O'Reilly and Chatman, 1996; Schein, 1992), or profession (Sirmon and Lane, 2004) in which they are embedded. Hence, these managers tend to make distinct strategic decisions and also have diverse constraints and capabilities in their decision-making process, depending on the country in which they are operating.

We know from the more established business ethics literature that there is a strong relationship between the likelihood that a manager will engage in corrupt business behavior and the extent to which managers operate in countries with high power distance, masculinity, and uncertainty (Husted, 1999). In this regard, 
one conceptual framework to compare how managers' attitudes towards CSR might vary across countries can be done by testing the cross-national validity of Donaldson and Dunfee's (1999) integrative social contracts theory as extended to CSR. This research could explore whether hypernorms or fundamental principles such as 'people should not be forced to work excessive hours and under inhumane conditions' are constant across societies, but local norms such as 'allowing some degree of child labor in very controlled circumstances is acceptable' - vary across countries. In addition, there are a number of empirical studies systematically comparing managerial ethical reasoning across countries which the CSR field could use as a benchmark. For example, Spicer et al. (2004) have conducted an empirical analysis that compares responses on an ethics survey from Americans working in Russia and in the United States. They show that location had little effect on these managers' attitudes towards hypernorms, but it did have a significant effect on their attitudes towards local norms and how expatriates address ethical dilemmas outside the United States. And Cullen et al. (2004) draw on institutional anomie theory, which takes into account cultural values and social institutional effects on individuals' behavior, and use the World Values Survey, to test managers' unethical conduct in 28 countries. They find significant nation-level effects, for instance, that industrialization weakens social norms and triggers a win-at-all-costs mentality, or that in societies with strong cultural values such as universalism and materialism managers tend to engage in more egoistic ethical reasoning.

There exist a few empirical studies which show cross-national differences in managerial attitudes towards CSR. We discuss four of them below to illustrate the distinct dimensions that comparative CSR has taken and ultimately to encourage other scholars to continue this research venue (the comparative CSR field), which remains fairly unexplored. The work that we discuss exemplifies the variety of research designs and countries covered. Then, we conclude this section by discussing another set of studies which do not see country-level variables as main drivers of CSR managerial attitudes and strategies, and point us towards somewhat mixed findings. This lack of consistent findings can be explained, in part, by the lack of a universal definition of CSR. It is not surprising that when individuals fill in surveys in different countries they have very distinct mental maps and expectations of what CSR is and is not, what it should be in an ideal world, and who should be involved in CSR issues. As Fukukawa and Moon (2004) have brought to our attention, even the definition of such terms as 'business' varies between countries, such that the Japanese word for business is a 'compound of the words kei, meaning "governing the world in harmony while bringing about the well-being of the people," and ci, meaning making "ceaseless efforts to achieve" .

First, Orpen (1987) conducted a survey among senior managers in South Africa and the United States to uncover their attitude towards CSR. One part of the survey was designed to assess managers' 'major arguments for and against involvement in social responsibility activities by business' (p. 90) and another part of the survey 
was designed to assess managers' 'perceptions of the extent to which their society regards it as desirable that business engage in various socially responsible activities' (p. 91). Orpen (1987) finds that US managers hold a much more positive attitude towards CSR activities than South African managers. In other words, US managers agreed more with pro-responsibility statements while South African managers tended to support more anti-responsibility arguments, and differences were stronger when referring to social as opposed to environmental issues. Moreover, it is also shown that US managers felt more pressure to get involved in CSR strategies than their counterparts in South Africa.

Second, Maignan and Ralston (2002)'s cross-national study shows that businesses' communication about CSR, as evaluated by the information displayed in the 100 largest company web pages in 1999 in France, the Netherlands, the UK, and the United States, varies significantly. Maignan and Ralston concluded that businesses in these four countries do not ascribe the same importance to managing their image as a socially responsible organization, and that businesses draw on different mechanisms in different countries to communicate the nature of their CSR principles, processes, and stakeholder issues. For example, US and UK firms tended to be more eager to show that they 'cared' about CSR issues, at least, on the surface, whereas Dutch and French firms were more likely to include CSR issues in their websites only as a response to stakeholders' scrutiny and pressures. Maignan and Ralston (2002) also show variance across these four industrialized OECD countries in the principal motivations for CSR, whether these were mostly performance-driven, as in the UK, an extension of their core company values, as in the United States, or a combination of performance-driven, values-driven, and stakeholder-driven, as was the case with Dutch and French firms. Lastly, stakeholders' pressure on companies to address CSR issues also differed across countries. Maignan and Ralston (2002) show that communities and consumers were the primary stakeholder drivers in the UK, while customers and regulators were more salient in France and the Netherlands.

More recently, Waldman et al. (2006) published an extensive cross-national study of 561 firms based in 15 countries, on five continents, which examines the relation between CSR values of top management team members and two country-level societal cultural constructs, institutional collectivism and power distance, among other individual-level constructs. Their societal culture values are based on the Global Leadership and Organizational Behavior Effectiveness (GLOBE) research project (House et al., 2004), where institutional collectivism is defined as 'the extent to which a collective should believe in encouraging and rewarding the collective distribution of resources and collective action, and emphasizes group performance and rewards' (p. 826); and power distance refers to the degree which a culture believes that power should be unequally distributed. (High power distance societies tend to be more stratified economically, socially, and politically.) For example, Brazil scores high in institutional collectivism and China scores high in power 
distance, according to the GLOBE scores. In addition, managerial CSR values are conceptualized and measured as a multidimensional construct where managers can identify with three different dimensions of CSR: shareholder/owner, stakeholder issues, or community/state welfare. Waldman et al. (2006) show that managers in countries which esteem institutional collectivism traits such as obtaining gratification for addressing long-term concerns, and devalue high power distance traits, are more likely to manifest managerial behaviors positively associated with the three dimensions of CSR. In addition, they show that managers in wealthier countries are mostly concerned with shareholder/owner CSR issues, that is, CSR strategies which maximize economic returns.

Similarly, Egri et al. (2006) have conducted an extensive multi-level study which looks at the individual and national effects on attitudes towards corporate responsibilities (CR) in 28 countries. One of the key differences with Waldman et al. (2006) is that Egri et al.'s macro-level variable draws on two different societal cultural values included in the World Values Survey developed by Inglehart (1997), which are: traditional/secular-rational and survival/self-expression cultural values. The additional contribution of this study is that in their analysis of what influences corporate responsibility outcomes across countries, the authors differentiate three different types of corporate responsibility (social, environmental, and economic) and also account for three country-level factors (societal culture, degree of government intervention, and trade openness). In addition to reporting that personal values have a direct relationship with the type of CR that managers are likely to support in different countries, Egri et al. (2006) show that managers in traditional cultures that promote ethical idealism and communitarian norms, and tend to have a Roman Catholic heritage (e.g. Colombia and Italy) were more supportive of social CR than environmental or economic CR. Secular-rational and survival societies such as ex-Communist countries (e.g. Croatia and Hungary) or Confucian-oriented societies (e.g. Taiwan and Hong-Kong) were more likely to support economic CR initiatives.

As mentioned before, other comparative studies have not so clearly concluded that national cultural and market settings are strong predictors of managerial CSR behavior. Instead, they put more weight on the values of individuals and organizations regardless of country or regional institutional and cultural context. For example, Quazi (1997) and a follow-up study by Quazi and O'Brien (2000) comparing textile and food manufacturers in two very different countries, Australia and Bangladesh, find that managerial CSR decision-making in these two countries tends to be more universal than country-driven and that individual differences are mostly two-dimensional in terms of the span of corporate responsibility and the range of outcomes of social commitments of businesses, as opposed to culturally driven.

Similarly, Bansal and Roth (200o) have conducted an excellent qualitative study which looked at two broad conceptual categories of determinants of managerial 
ecological responsiveness in two countries, the UK and Japan. On the one hand, they examine corporate-level motivations such as competitiveness, legitimation, and degree of overall environmental responsibility, and on the other hand, they explore the contextual determinants defined as the level of cohesion within a given industry, the salience of the given CSR issue, and the managerial individual concern for CSR issues. They are able to conclude that managers and firms in these two countries are driven by distinct factors to pursue positive CSR actions although there is not an explicit country-level cleavage. Instead, the authors remind us that ecological responsiveness exemplifies configurational equifinality, that is, firms, regardless of their country of origin, can reach the same final state of responsiveness from differing contextual and motivational conditions and taking distinct paths to reach that same outcome.

\section{Comparative Consumer Attitudes towards CSR}

Consumers are an important stakeholder in the context of CSR and can become strategic nightmares for companies, as Nike experienced when it became a lightning rod for concerns over labor practices in Asia, or as Royal Dutch Shell experienced with the Brent Spar environmental imbroglio. Marketing research has demonstrated that corporate social performance information shapes consumer purchase intentions (e.g. Brown and Dacin, 1997; Creyer and Ross, 1997). There also exits a fascinating literature drawing on social movement theory which discusses consumers' capabilities, strategies and ultimately power as an organized group to impact firms' CSR behavior (e.g. Kozinets and Handelman, 2004; O'Rourke, 2005; Schurman, 2004; Sharma and Vredenburg, 1998). However, the research on comparative consumer attitudes toward CSR is less developed, and certainly less abundant, than the comparative managerial work reviewed in the previous section.

Isabelle Maignan and her colleagues have offered pioneering insights into the field of marketing research and CSR, or the so-called 'socially responsible buying' behavioral literature, by asking what differences there are across countries regarding the extent to which consumers support socially responsible business. For example, Maignan's (2001) study is one of the first cross-national comparative studies of consumer attitudes towards CSR and of the demands that this group of stakeholders is willing to make on firms. Maignan (2001) collected consumer survey data in France, Germany, and the United States, and concluded that American consumers are mostly concerned with corporate economic responsibilities, agreeing with such statements as business must 'maximize profits' and 'control their production costs strictly' (p. 64), as opposed to statements emphasizing companies' legal, ethical, and philanthropic responsibilities. Meanwhile, French and German consumers generally tend to put more value on supporting socially responsible organizations conforming with legal and ethical standards, and have better mechanisms and tactics in 
place to monitor and influence the behavior of organizations as a consumer group (see also Maignan and Ferrell, 2003 for a follow-up study).

More recently, Schuler and Cording (2006) have developed a conceptual model of consumer behavior based on the process by which consumers make purchasing decisions, as affected by different characteristics of information intensity, such as information source, degree of diffusion, and corporate reputation, to explain the complex relationship between corporate social performance (CSP) and corporate financial performance. It would be worthwhile to test their consumer behavioral model in different industry and national settings. In addition, some researchers have examined the role of marketing professionals and their perception of consumers in CSR issues. For example, Singhapakdi et al. (2001) compare the attitudes of marketing professionals when assessing consumer preferences in Australia, Malaysia, South Africa, and the United States. This might be another interesting route to take in exploring consumer attitudes and behavior towards firms' CSR. Finally, it is important to note that while there are societies that place a lot of emphasis on consumers' voice and have in place direct mechanisms where they can express their concerns, such as in the France, this is not the case in other societies, such as in Japan, where the consumer movement has been relatively weak (Wokutch, 1990).

\section{Behavior-Centered Cross-National COMPARISONS}

A different comparative approach is to examine companies' CSR behaviors, such as sustainability reporting or $\mathrm{NGO/company} \mathrm{partnerships,} \mathrm{across} \mathrm{countries.} \mathrm{A} \mathrm{num-}$ ber of these studies have looked at companies' sustainability reporting, evaluating differences across countries in reporting rates, in the issues discussed, and in how CSR issues are framed. Studies consistently find that reporting rates are highest in Europe, followed by Japan, and with the United States showing the lowest rates of reporting among comparable companies (Kolk, 2003; KPMG, 2005; Kolk, forthcoming; Welford, 2005). Kolk's most recent study shows that 90\% of European companies in the Fortune Global 250 publish sustainability reports, followed by $83 \%$ of Japanese companies, as contrasted with $35 \%$ of American companies. Kolk suggests that this dramatic differential between Europe and the United States reflects cross-national differences in public discussion of CSR and sustainability reporting and European leadership in CSR (Kolk, forthcoming: 6), while it must be noted that Europe requires social and environmental reporting, albeit without being specific about the format. Of course, the fact that Europe requires some aspects 
of sustainability reporting can also be understood as evidence of its leadership on CSR.

Interesting differences emerge in what issues are emphasized in companies' sustainability reports and how those issues are framed. Kolk finds that about $60 \%$ of sustainability reports now discuss the corporate governance of sustainability within the organization, while surveys of similar sets of companies only a few years ago (2002 reports) did not discuss this topic (Kolk, forthcoming). Kolk also finds that European and Japanese companies are more specific than US companies about 'the organizational aspects and responsibilities for sustainability' (Kolk, forthcoming: 8). Differences also emerge in external verification of sustainability reports, with $45 \%$ of European reports being externally verified, as contrasted with $24 \%$ of Japanese reports and 3\% of American reports (Kolk, 2006: 10 and table 3). As Kolk recognizes, American disclosure patterns and lack of verification may reflect the greater concern with litigation in the United States, and the difficulties of a purely voluntary approach to expanded sustainability disclosure in such a context. Further comparative research that investigates the decisions by TMTs to produce sustainability reports, and their understanding of their own motivations for the structure, contents, and verification of such reports, would be of value.

Country of origin also has an impact on how multinationals as legal entities incorporated in a given home country behave around the world through their subsidiaries. For example, Meek et al. (1995) have conducted a study of voluntary annual report disclosure by US, UK, and Continental European multinational firms. They are able to show that the country of origin has a significant effect not only on the degree of voluntary disclosure but also on what type of information (i.e. strategic, non-financial, and financial) is most likely to be covered in these $\mathrm{MNCs}^{\prime}$ annual reports.

Despite the transnational efforts to design and implement universal CSR standards connected to 'triple bottom line' thinking (Waddock et al., 2002), in practice international hard regulation on and enforcement of how MNCs should behave around the world is non-existent. It is interesting to examine to what degree MNCs from different parts of the world comply with soft international regulation. For example, Christmann and Taylor (2006) look at MNCs' compliance with ISO gooo (a set of international environmental standards) in China, which allows them to control for the host country enforceability of regulation. They discover that MNC compliance with this environmental standard, whether it is substantive or symbolic, is determined by customer preferences, customer monitoring, and expected sanctions from customers in their home countries. This study suggests a fruitful line of inquiry evaluating the relative efficacy of legal versus market 'enforcement' of standards.

Another comparative approach to the study of CSR within MNCs is to examine whether there are differences in practices not only between the home MNC and the 
subsidiaries, but also across the different subsidiaries of a given MNC. Husted and Allen (2006) have investigated how CSR is managed within MNCs, and studied the relationship between global and local (country-specific) CSR. Building upon Donaldson and Dunfee (1994: 260), they define global CSR issues as those 'issues that transcend national boundaries and about which considerable consensus is emerging', such as human rights and environmental protection (Husted and Allen, 2006: 840). Local CSR issues are those that respond to the specific needs and concerns of particular communities, such as HIV/AIDS in Africa: it is an issue that every company doing business in Africa needs to address, but it has not become part of the global CSR agenda. Husted and Allen (2006) surveyed firms in Mexico, and found that the firms followed different patterns of management of global and local CSR issues depending on whether they were firms with many, semiautonomous subsidiaries (multi-domestic); were organized from a central office with lean subsidiaries (global); or combined elements of central organization and local responsiveness (transnational). Following Husted and Allen's (2006) suggestion, these results can be useful in evaluating government policies in developing countries to encourage greater economic development. For instance, comparative research might study whether decisions about valuable licenses to operate or to extract local resources would best be granted to specific types of firms (global, multi-domestic, transnational), depending on the mix of local versus global CSR issues in the region or industry at issue.

\section{CONCLUSION}

The field of comparative CSR, ultimately, addresses a research question of critical practical importance: how best to structure global enterprise to import best practice in CSR in order to produce economic development that is consistent with raising labor standards and encouraging environmental protection. Strike et al. (2006) have produced empirical evidence that clearly states the challenge, by virtue of their findings that international diversification of firms increases both CSR as well as corporate irresponsibility, given the difficulties of managing semi-autonomous subsidiaries in different countries. Further comparative investigations of the respective roles of government; institutional actors such as labor unions, investors, and NGOs; and actors within the firm, such as TMTs and employees, are necessary to further our understanding of the differing pressures from consumers, cultures, and political entities towards responsible corporate actions. Such research may provide an empirical and theoretical basis for developing policies to encourage CSR and for conceptualizing which kinds of pressures are likely to be effective in encouraging a positive relationship between international businesses and society. 


\section{REFERENCES}

Aaronson, S., and Regves, J. 2002. Corporate Responsibility in the Global Village: The Role of Public Policy. Washington: National Policy Association.

Aguilera, R. V., and Jackson, G. 2003. 'The Cross-National Diversity of Corporate Governance: Dimensions and Determinants'. Academy of Management Review, 28: 447-65.

Williams, C., Conley, J., and Rupp, D. 2006. 'Corporate Governance and Corporate Social Responsibility. A Comparative Analysis of the U.K. and the U.S.' . Corporate Governance: An International Review, 14(3): 147-57.

- Rupp, D., Williams, C., and Ganapathi, J. Forthcoming. 'Putting the S Back in CSR: A Multi-level Theory of Social Change in Organizations'. Academy of Management Review. Ahlering, B. and Deakin, S. 2005. 'Labour Regulation, Corporate Governance and Legal Origin: A Case of Institutional Complementarity?' European Corporate Governance Institute, Law Working Paper No. 72/2006.

Aman, A., Jr. 2001. 'Privatization and the Democracy Problem in Globalization: Making Markets More Accountable through Administrative Law'. Fordham Urban Law Journal, 28: $1477-506$.

Armour, J., Deakin, S. and Konzelmann, S. J. 2003. 'Shareholder Primacy and the Trajectory of UK Corporate Governance'. British Journal of Industrial Relations, 41(3): 53155 .

Bansal, P., and Roth, K. 2000. 'Why Companies Go Green: A Model of Ecological Responsiveness'. Academy of Management Journal, 43: 717-36.

Barnett, M. L., and Salomon, R. M. 2006. 'Beyond Dichotomy: The Curvilinear Relationship between Social Responsibility and Financial Performance'. Strategic Management Journal, 1101-22.

Branzei, O., Ursacki-Bryant, T. J., , Vertinsky, I., and Zhang, W. 2004. 'The Formations of Green Strategies in Chinese Firms: Matching Corporate Environmental Responses and Individual Principles'. Strategic Management Journal, 25: 1075-95.

Brown, T. J., and DACin, P. A. 1997. 'The Company and the Product: Corporate Associations and Consumer Product Responses. Journal of Marketing, 61: 68-84.

Campbelt, J. 2005. Institutional Change and Globalization: Exploring Problems in the New Institutional Analysis. Princeton: Princeton University Press.

Carroll, A. 1979. 'A Three-Dimensional Model of Corporate Performance'. Academy of Management Review, 4: 497-505.

Chapple, W., and Moon, J. 2005. 'Corporate Social Responsibility (CSR) in Asia: A SevenCountry Study of CSR'. Business and Society, 44(4): 415-41.

Christmann, P., and TAYLor, G. 2006. 'Firm Self-Regulation through International Certifiable Standards: Determinants of Symbolic versus Substantive Implementation. Journal of International Business Studiès, 37: 863-78.

Clafkson, M. 1995. 'A Stakeholder Framework for Analyzing and Evaluating Corporate Social Performance'. Academy of Management Review, 20: 92-117.

Creyer, E. H., and Ross, W. T. 1997. 'The Influence of Firm Behavior on Purchase Intention: Do Consumers really Care about Business Ethics?' Journal of Consumer Marketing, 14: 421-32.

Cuesta González, M., and Valor Martínez, C. 2004. 'Fostering Corporate Social Responsibility through Public Initiative: From the EU to the Spanish Case'. Journal of Business Ethics, 55: 273-93. 
Cullen, J. B., Parboteeah, K. P., and Hoegl, M. 2004. 'Cross-National Differences in Managers' Willingness to Justify Ethically Suspect Behaviors: A Test of Institutional Anomie Theory'. Academy of Management Journal, 47: 411-21.

DEAKIN, S. 2005. 'The Coming Transformation of Shareholder Value'. Corporate Governance: An International Review, 13(1): 11-18.

Diamond, S. F. 2003. 'The "Race to the Bottom" Returns: China's Challenge to the International Labor Movement'. University of California at Davis Journal of International Law and Policy, 10: 39-74.

DoH, J. P., and GuAY, T. R. 2006. 'Corporate Social Responsibility, Public Policy, and NGO Activism in Europe and the United States: An Institutional-Stakeholder Perspective'. Journal of Management Studies, 47-73.

Donaldson, T., and Dunfee, T. W. 1994. 'Toward a Unified Conception of Business Ethics: Integrative Social Contracts Theory'. Academy of Management Review, 19: 252-84.

1999. Ties that Bind. A Social Contracts Approach to Business Ethics. Boston: Harvard Business Review.

- and Preston, L. 1995. 'The Stakeholder Theory of the Corporation: Concepts, Evidence, and Implications'. Academy of Management Review, 20: 65-91.

Egri, C. P., Ralston, D. A., Milton, L., Casado, T., Palmer, I., Ramburuth, P., Wangenheim, F., Fu, P. P., Kuo, M. H., Carranza, M. T. G., Girson, I., Dabic, M., Butt, A., Srinvasan, N., Furrer, O., Hallinger, P., Dalgic, 'T., Richards, M., Rossi, A. M., Danis, W., Gutirez, J. R., Reynaud, E., Brock, D., Molteni, M., Starkus, A., Castro, F., Chia, H. B., Darder, F. L., Wallace, A., Naoumova, I., Ansari, M., Riddel, L., Potocan, V. V., and Thanh, H. V. 2006. 'The Influence of Personal Values and National Contexts on Attitudes towards Corporate Responsibilities'. Presented at the Third BC Organizational Behaviour Conference, Vancouver, Canada.

Freeman. R. E. 1984. Strategic Management: A Stakeholder Perspective. Englewood Cliffs, NJ: Prentice Hall.

Fukukawa, K., and Moon, J. 2004. 'A Japanese Model of Corporate Social Responsibility? A Study of Website Reporting. Journal of Corporate Citizenship, 16: 45-60.

Hay, R., and Gray, E. 1974. 'Social Responsibilities of Business Managers'. Academy of Management Journal, 17: 135-43.

HeвB, T., and Wojcik, D. 2004. 'Global Standards and Emerging Markets: The Institutional Investor Value Chain and CALPERS' Investment Strategy'. University of Oxford Working Paper 04-05, available at <http://www.ssrn.com/author=202581 >.

Hemingway, C. A. 2005. 'Personal Values as a Catalyst for Corporate Social Entrepreneurship'. Journal of Business Ethics, 60(3): 233-49.

— and Maclagan, P. W. 2004. 'Managers' Personal Values as Drivers of Corporate Social Responsibility'. Journal of Business Ethics, 50(1): 33-44.

Hofstede, G. 1980. Culture's Consequences: International Differences in Work-Related Values. Beverly Hills, Calif.: Sage.

-2001. 'Culture's Consequences: Comparing Values, Behaviours, Institutions, and Organizations across Nations and edn. Thousand Oaks, Calif.: Sage.

House, R. J., Hanges, P. M., Javidan, M., Dorfman, P., and Gupta, V. 2004. Culture, Leadership and Organizations: The GLOBE Study of 62 Societies. Thousand Oaks, Calif: Sage.

Husted, B. W. 1999. 'Wealth, Culture and Corruption'. Journal of International Business Studies, 30: 339-60. 
Husted, B. W., and Allen, D. B. 2006. 'Corporate Social Responsibility in the Multinational Enterprise: Strategic and Institutional Approaches'. Journal of International Business Studies, 37: 838-49.

Inglehart, R. 1997. Modernization and Postmodernization: Cultural, Economic, and Political Change in 43 Societies. Princeton: Princeton University Press.

Kagan, R. A., Gunningham, N., and Thornton, D. 2003. 'Explaining Corporate Environmental Performance: How does Regulation Matter?' Law and Society Review, 37: 51-90.

KolK, A. 2003. 'Trends in Sustainability Reporting by the Fortune Global 250'. Business Strategy and the Environment, 12: 279-91.

— Forthcoming. 'Sustainability, Accountability and Corporate Governance: Exploring Multinationals' Reporting Practices'. Business Strategy and the Environment.

Kozinets, R. V., and Handelman, J. M. 2004. 'Adversaries of Consumption: Consumer Movements, Activism, and Ideology'. Journal of Consumer Research, 31: 691-704.

KPMG. 2005. 'KPMG International Survey of Corporate Responsibility Reporting 2005'. Amsterdam: KPMG Global Sustainability Services.

Lessig, L. 1999. Code and other Laws of Cyberspace. New York: Basic Books.

Licht, A. N. 2004. 'The Maximands of Corporate Governance: A Theory of Values and Cognitive Style'. Delaware Journal of Corporate Law. 29: 649-746.

Logsdon, J., and Wood, D. J. 2002. 'Business Citizenship: From Domestic to Global Level of Analysis'. Business Ethics Quarterly, 12: 155-88.

McAdams, R., and Nadler, J. 2005. 'Testing the Focal Point Theory of Legal Compliance: The Effect of Third-Party Expression in an Experimental Hawk/Dove Game'. Journal of Empirical Legal Studies, 87-123.

McWilliams, A., and Siggel, D. 2000. 'Corporate Social Responsibility and Financial Performance: Correlation or Misspecification?' Strategic Management Journal, 21: 603-10.

2001. 'Corporate Social Responsibility: A Theory of the Firm Perspective', Academy of Management Review, 26: 117-27.

and Wright, P. 2006. 'Corporate Social Responsibility: Strategic Implications'. Journal of Management Studies, 43: 1-18.

Maignan, I. 2001. 'Consumer's' Perception of Corporate Social Responsibilities: A CrossCultural Comparison'. Journal of Business Ethics, 30: 57-72.

— and Ferrell, O. C. 2003. 'Nature of Corporate Responsibilities: Perspectives from American, French and German Consumers'. Journal of Business Research, 56: 55-67.

Maignan, I., and Ralston, D. 2002. 'Corporate Social Responsibility in Europe and the U.S.: Insights from Businesses' Self-Presentations'. Journal of International Business Studies, 33: 497-514.

Margolis, J. D., and Walsh, J. P. 2003. 'Misery Loves Companies: Rethinking Social Initiatives by Business'. Administrative Science Quarterly, 48: 655-89.

MATten, D., and Moon, J. 2004. "Implicit" and "explicit" CSR: A Conceptual Framework for Understanding CSR in Europe', in A. Habisch, J. Jonker, M. Wegner and R. Schmidpeter (eds.), CSR across Europe. Berlin: Springer-Verlag, 335-56.

Meex, G., Roberts, C., and Gray, S. 1995. 'Factors Influencing Voluntary Annual Report Disclosures by U.S., U.K. and Continental European Multinational Corporations'. Journal of International Business Studies, 26: 555-73.

Moon, J. 2004. 'Government as a Driver of Corporate Social Responsibility: The UK in Comparative Perspective'. International Centre for Corporate Social Responsibility Research Paper No. 20-2004, Nottingham: Nottingham University Business School. 
O'Reilly, C., and Chatman, J. 1996. 'Culture as Social Control: Corporations, Cults, and Commitment'. Research in Organizational Behavior, 18: 157-200.

Orlitzky, M., Schmidt, F. L., and Rynes, S. L. 2003. 'Corporate Social and Financial Performance: A Meta-analysis'. Organization Studies, 24: 403-41.

O'Rourke, D. 2005. 'Market Movements. Nongovernmental Organization Strategies to Influence Global Production and Consumption'. Journal of Industry Ecology, 9: 1-14.

Orpen, C. 1987. 'The Attitudes of United States and South African Managers to Corporate Social Responsibility'. Journal of Business Ethics, 6: 89-96.

QuAzI, A. M. 1997. 'Corporate Social Responsibility in Diverse Environments: A Comparative Study of Managerial Attitudes in Australia and Bangladesh'. Business and Professional Ethics Journal, 16: 67-84.

— and O'Brien, D. 2000. 'An Empirical Test of a Cross-National Model of Corporate Social Responsibility'. Journal of Business Ethics, 25: 33-51.

Rodríguez, P., Siegel, D. S., Hillman, A., and Eden, L. 2006. 'Three Lenses on the Multinational Enterprise: Politics, Corruption, and Corporate Social Responsibility'. Journal of International Business Studies, 37: 733-46.

Schein, E. H. 1992. Organizational Culture and Leadership. San Tranciso: Jossey-Bass.

Schuler, D. A., and Cording, M. 2006. 'A Corporate Social Performance-Corporate Financial Performance Behavioral Model for Consumers'. Academy of Management Review, 31: $540-58$.

Schurman, R. 2004. 'Fighting "Frankenfoods": Industry Opportunity Structures and the Efficacy of the Anti-biotech Movement in Western Europe'. Social Problems, 51: 243-68.

Schwartz, S. H. 1994. 'Cultural Dimensions of Values: Towards an Understanding of National Differences', in H. C. Kim, C. Triandis, C. Kagitcibasi, S. C. Choi, and G. Yoon (eds.), Individualism and collectivism: Theoretical and Methodological Issues. Thousand Oaks, Calif:: Sage, 85-119.

ScotT, C. 2003. 'Regulation in the Age of Governance: The Rise of the Post-regulatory State', in J. Jordana and DD. Levi-Faur (eds.), The Politics of Regulation. Cheltenham: Edward Elgar.

Sharma, S., and Vredenburg, H. 1998. 'Proactive Corporate Environmental Strategy and the Development of Competitively Valuable Organizational Capabilities'. Strategic Management Journal, 19: 729-53.

Singhapakdi, A., Karande, K., Rao, C. P., and Vitell, S. J. 2001. 'How Important are Ethics and Social Responsibility? A Multinational Study of Marketing Professionals'. European Journal of Marketing, 35(1-2): 133-45.

Sirmon, D. G., and LANe, P. J. 2004. 'A Model of Cultural Differences and International Alliance Performance', Journal of International Business Studies, 35: 306-19.

SPICER, A., DunfeE, T. W., and BAILEY, W. J. 2004. 'Does National Context Matter in Ethical Decision Making? An Empirical Test of Integrative Social Contracts Theory'. Academy of Management Journal, 47: 610-20.

Strike, V. M., GAo, J., and Bansal, P. 2006. 'Being Good While Being Bad: Social Responsibility and the International Diversification of US Firms. Journal of International Business Studies, 37: 850-62.

Triandis, H. C. 1995. Individualism and Collectivism. Boulder, Colo.: Westview Press.

Vitell, S. J., and Paolillo, J. G. 2004. 'A Cross-Cultural Study of the Antecedents of the Perceived Role of Ethics and Social Responsibility'. Business Ethics, 13 (2-3): 185-99. 
Waddock, S. A., Bodwell, C., and Graves, S. B. 2002. 'Responsibility: The New Business Imperative'. Academy of Management Executive, 16: 132-48.

Waldman, D. A., Sully de Luque, M., Washburn, N., and House, R. J. 2006. 'Cultural and Leadership Predictors of Corporate Social Responsibility Values of Top Management: A GLOBE Study of 15 countries'. Journal of International Business Studies, 37: 823-37.

Welford, R. 2005. 'Corporate Social Responsibility in Europe, North America and Asia'. Journal of Corporate Citizenship, 17: 33-52.

Wrilrams, C. A. 2004. 'Civil Society Initiatives and 'Soft Law' in the Oil and Gas Industry'. New York University Journal of International Law and Politics, 36: 457-502.

— and CONLEY, J. 2005. 'An Emerging Third Way? The Erosion of the Anglo-American Shareholder Value Construct'. Cornell International Law Journal, 38(2): 493-551.

Woкuтch, R. E. 1990. 'Corporate Social Responsibility Japanese Style'. Academy of Management Executive, 42: 56-74.

Zumbansen, P. 2006. 'The Conundrum of Corporate Social Responsibility: Reflections on the Changing Nature of Firms and States', in R. Miller and R. Bratspies (eds.), Transboundary Harm: Lessons from the Trail Smelter Arbitration. Cambridge: Cambridge University Press. 